\title{
The Contentious Politics of Hospitality: Intra-EU Mobility and Social Rights
}

\author{
Maurizio Ferrera*
}

\section{Introduction}

The intra-EU mobility of workers/persons, and in particular the latter's access to the so- Q1 cial protection systems of the receiving countries, has become a highly contentious and polarising issue at both the national and supranational levels. Its normative basis, i.e. the principle of non-discrimination, has lost its symbolic appeal and political purchase among vast sectors of public opinion, feeding Eurosceptic orientations. The already preoccupying scenario of a 'Fortress Europe', closed vis-à-vis the outside, risks being superseded by an even more alarming prospect, i.e. the EU's regress into a 'fortress of fortresses', crossed by internal fences hindering free movement and barring access to national social protection schemes. Such prospect is alarming in cultural and economic terms, but even more so in political terms. No territorial collectivity - and definitely not a liberal democratic one-can survive and prosper without internal openness, underpinned by solidaristic norms, institutions and dispositions.

Solidarity is a contested concept, but its prime meaning is relatively straightforward: it connotes a specific trait of social collectivities, that is, a high degree of 'fusion' or internal unity, cohesion and commonality of purpose (the noun 'solidarity' comes from the Latin solidus, a firm and compact body). In this basic, 'realist' sense, solidarity must be considered - first and foremost - as a political good, i.e. a state of affairs which serves the key purpose of facilitating social cooperation, containing conflicts and sustaining generalised compliance within a spatially demarcated community. Just like security and peace, organised solidarity is a necessary condition for a stable and effective functioning of both the market and democracy and for mediating their inevitable tensions. The current political predicament of the EU can partly be explained by the weak institutionalisation of a pan-European solidarity, capable of buttressing the 'solidity' (and thus the persistence and stability) of the Union as such.

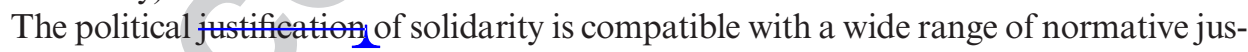
tifications, typically anchored to first principles. Normative arguments have an intrinsic value of their own in the epistemic sphere, but are not disconnected from the sphere of practice, which requires cognitive anchoring and normative legitimation. Politics plays a key role in both processes, especially the latter. To some extent, all public policies (including market-making policies) contain a 'moral project' and are imbued with normativity. ${ }^{1}$ A dialogue between policy makers and practical philosophers can thus be very productive. For this to happen, however, normative justifications must be sensitive to feasibility constraints and to their empirical implications. In a 'realist' perspective, the status quo ought to be the starting point for any exercise of principled reasoning: not in the ate of some ideologically conservative bias in favour of the status quo, but rather for keeping in due

\footnotetext{
* Professore Ordinario, Universitá degli Studi di Milano, Italy.

1 J. Beckert, 'The Social Order of Markets', (2009) 38 Theory and Society, 245-269.
} 
consideration the basic requirements of 'polity maintenance', i.e. the conditions under which a territorial collectivity is able to remain 'solid' and persist over time.

The aim of this article is to discuss the current, increasingly contentious politics of intraEU mobility of workers and persons against the backdrop of pan-European solidarity and its weak institutionalisation. The discussion will rest on both empirical and normative reconstructions, adopting a realist perspective on the link between facts and principles. The next section will provide a brief historical summary of welfare state building at the national level, highlighting the salience of boundaries and of the 'bounding-bonding' nexus. It will also discuss the problems encountered by European integration in dealing with the question of social rights and the promotion of a pan-European solidarity. Section III will focus on the latter, distinguishing between cross-national and transnational solidarity and their distinet underlying logics. Sections IV and V will concentrate on transnational solidarity and on its main current challenge, i.e. free movement and access to benefits. It will be argued that the most promising normative framing of this issue is through the principle of 'hospitality', rather than non-discrimination. A few options will be discussed in Section VI in order to translate this principle into politically sustainable institutional changes. Conclusions are presented in the final section.

\section{The Spatial Politics of Solidarity}

In the European context, social solidarity was gradually recognised as a matter of public responsibility during the last two centuries, within the wider process of bution bulling. Modern welfare programmes pooled across the population some typical risks of the life cycle: from sickness to old age, from work accidents to unemployment. By redistributing resources horizontally (from the non-damaged to the damaged) and vertically (from the better-off to the worse-off), the new public insurance schemes served both efficiency and social justice objectives. They also stabilised people's life chances by anchoring them to state-national organisations uniquely dedicated to social protection. Weaving social entitlements into the fabric of citizenship was no easy task. In the economic sphere, the logic of market capitalism produced a class society inherently built on inequalities, differential rewards and the 'commodification' of workers. ${ }^{2}$ And even though the virtuous reconciliation between the meritocratic logic of the capitalist market and the egalitarian logic of national citizenship has been one of the greatest achievements of twentieth-century Europe, the march towards this destination was punctuated by marked strains and clashes.

Welfare rights had an enormous impact on social stratification and life chances. As famously highlighted by Korpi and Esping-Andersen, ${ }^{3}$ these rights played a key role in 'de-commodifying' wage-earners and provided labour movements with precious power resources for the 'democratic class struggle'. The quest for solidarity and egalitarian policies was accompanied by the diffusion of justice-oriented and collectivist ideologies, which legitimised redistributive claims from a normative and political viewpoint. But 'decommodification' through class conflict was not the only issue that shaped the forms and content of social rights in $\_$various countries. Another important frent was the issue 括 closure: how far-reaching ought the new redistributive schemes be? For which collectivities ought the new sharing ties be defined and introduced? Such 'who' questions were as important as the 'what' questions emphasised by outcome-oriented debates.

\footnotetext{
${ }^{2}$ K. Polanyi, The Great Transformation: The Political and Economic Origins of Our Time (Beacon Press, 1957), G. Esping-Andersen, The Three Words of Welfare Capitalism (Polity Press, 1990).

${ }^{3}$ W. Korpi, The Democratic Class Struggle (Routledge, 1983), Esping-Andersen, above, n. 2.
} 
'Who' questions typically involve spatial dilemmas: the degree of spatial closure as such, to begin with, but also the link between rights, territory and membership to redistributive collectivities within that territory. ${ }^{4}$

Boundaries are essential for constructing new special purpose communities ready to pool risks. For welfare-state builders, boundary setting was a delicate balancing act between indulgence vis-à-vis the particularistic inclinations of pre-existing communities and the self-defeating ambitions of redistributive stretching, that is, pushing the scope of solidarity beyond the limits which could be sustained by available material and moral resources. Historically, on the territorial dimension the major challenge was to push through a process of institutional 'fusion' of local practices, regulated by their own formal and informal codes. The existence of strong peripheries, i.e. territories characterised by a tradition of cultural distinctiveness, political autonomy and economic independence, tended to disturb state centralisation and national standardisation. In such contexts, the removal of local boundaries and especially the fusion of pre-existing sharing ties and practices into a single 'national pot' encountered severe difficulties. The introduction of public compulsory insurance served, however, as a powerful engine of centralisation, allowing for greater cross-local uniformity and a gradual ironing out of territorial diversities in institutional structures and practices. Labour market positions, rather than territorial membership, became the driving force of welfare state developments. In most European countries_explicit cross-regional redistribution a much less salient political issue, which could be dealt with through a separate (and financially limited) set of measures, explicitly devoted to regional aid and development. It must be noted, however, that a significant degree of cross-regional subsidisation did tacitly take place through the public budget, especially via taxes and social insurance benefits.

The membership dimension of closure (Which are the relevant collectivities for redistribution? How to enforce 'bounding' in order to effectively pool resources?) was more controversial and required much heavier political investments than the territorial dimension. The internal design of the European welfare state (e.g. universal vs. categorical) was significantly shaped by pre-existing constellations of religious, linguistic, socio-economic and ideological cleavages. The drawing of internal membership boundaries gave rise to a web of redistributive collectivities and arrangements which became gradually crystallised through dynamics of institutionalisation. If observed through the lens of social citizenship circa 1970, the European landscape appeared as a dense forest of compulsory spaces of affiliation, covering virtually 100 per cent of national populations, with very limited exit opportunities (such as in the form of exemption from insurance) and stringent controls on the entry of aliens crossing state borders. In the course of the first half of the twentieth century, all European countries introduced or strengthened criteria for acquiring citizenship, thus putting in place effective filters to guard their territorial and membership spaces of redistribution.

Since the early 1970s the process of European integration started to gradually thin out the national boundaries of citizenship, with specific and significant implications for social rights. Through binding regulations and court rulings, social rights (and the corresponding obligations) have been de-coupled from national citizenship within the EU and linked merely to work or residence status. On this front, it is clear that European integration has promoted an almost complete cross-local 'fusion' of what Marshall considered the basic civil right in the economic sphere: 'the right to follow the occupation of one's choice in the place of one's choice, subject only to legitimate demands for preliminary technical

${ }^{4}$ M. Ferrera, The Boundaries of Welfare_(Oxford University Press, 2005). 
training. ${ }^{5}$ Contrary to the nation-state experience, the fusion prompted by integration has not been accompanied by institutional standardisation and resource centralisation. The Member States have remained the basic political entities of the Union and the duty of social protection linked to EU citizenship and free movement must be honoured by their domestic insurance/assistance systems. No common supranational pot has been created to insure risks on a functional, pan-European basis. Within the (limited) EU budget, a number of schemes have been established through time to promote territorial 'cohesion' and help backward regions. But the size of cross-national transfers is incomparable to what exists in contemporary federations, not to mention unitary states.

Building on the contrast between negative and positive integration, scholarly debates have extensively shown how the 'vertical' pressures of EU law and policies have increasingly led to a 'horizontal' re-balancing between markets and social rights in clear favour of the former. European integration has prompted changes that are more far-reaching than 'just' a mutual re-balancing of markets and states in response to social needs. What is at stake is the basic spatial architecture of solidarity, that is, its territorial and functional reach, the identity of its constituent communities, the direction and depth of resource transfers. National social programmes, backed by state authority, have played a crucial integrative role in domestic polities not only as mechanisms of redistribution, but also as lynchpins for group formation, voice structuring and loyalty generation. By challenging national boundaries and by redrawing these boundaries along different geographical, socio-economic and institutional lines, European integration can undermine, and thus de-structure deep-seated social and political equilibria, while being unable to promote adequate restructuring through the institutionalisation of pan-European solidarities. The financial crisis and the ensuing 'Great Recession' have brought to the fore burning questions of 'fairness' and solidarity among the 'peoples' of Europe and their individual citizens. Fairness questions in the relations among constituent units have given rise to harsh debates and conflicts in all historical federations (think of the US or Switzerland). We should not be surprised that such issues are becoming more salient today in the EU and, to some extent, we must look at this as a sign of maturation and collective reflexivity. There is, however, a tangible danger of excessive and destructive polarisation. As mentioned above, during the twentieth century the democratic class struggle was accompanied and guided by ideological frameworks which provided justificatory rationales for advancing redistributive claims in the political arena. What normative principles can be invoked today in order to frame the novel issue of pan-European solidarities and thus contrast polarisation at the ideational/political level?

\section{Two Types of Pan-European Solidarity}

Solidarity practices presuppose a floor of trust and mutual recognition among actors -individual and collective. In the EU context, the relevant actors are both the Member States and individuals EU citizenship. Any normative framework aimed at justifying and promoting forms of pan-European social sharing need to identify two distinct anchors: one for inter-territorial, cross-national solidarity and one for inter-personal, transnational solidarity - in particular as regards free movement and access to rights. In a realist perspective, principles must be selected in the wake of an accurate delineation of pertinent

\footnotetext{
${ }^{5}$ T.H. Marshall, 'Citizenship and Social Class', in T.H. Marshall (with an essay by T. Bottomore), Citizenship and Social Class (Pluto Press, 1992).
} 
facts. Let us briefly address, in turn, the factual bases on which the two types of European solidarity could build.

As to cross-national solidarity, the first question to ask is: what kind of associative relations link the Member States together? As I have argued elsewhere, ${ }^{6}$ the EU has become Q2 much more than a mere market association, but it is far from being a fully-fledged political community. It can rather be considered as a 'neighbourhood community', i.e. a group of nations (and 'states-peoples') characterised by durable spatial proximity and sharing a common project. Neighbours are not kin, linked by spontaneous 'ethicity' and altruism. Yet they have significant incentives to cooperate, especially in case of need and emergencies. Using a Weberian notion, the principle informing such cooperation can be defined as 'sober brotherhood': a brotherhood devoid of pathos, but nevertheless originating a disposition to cooperate beyond the perimeter of immediate mutual advantages. Given the fact of physical proximity - which in turns implies some degree of mutual interdependence and a joint experstan to certain risks - sober brotherhood among neighbours fosters relational orientations and exchanges that incorporate a reciprocity element, i.e. the readiness to give something now (e.g. offering financial help during a debt crisis) conditional upon receiving or having received something (with a relatively loose equivalence seale) in a different temporal moment.

Inter-personal, transnational solidarity follows a different logic. The distinctive trait of such solidarity is less a matter of a direct and explicit exchange of resources between spatially proximate territorial collectivities than of sharing a place with 'others'. The stake is not (only) whether to offer material help to outsiders, and certainly not a help from a distance, as in the case of cross-national transfers from a rich to a poor Member State. The stake is whether to accept a foreigner in one's place: an identity-thick geographical eontex, which is also a rights-thick membership context. Using a famous Swedish metaphor, the issue is who may enter into the Folkhemmet: the welfare state as the people's home - a national people.

The original rationale of free movement was essentially of a functional nature (marketmaking and thus greater economic growth). With the passing of time, a new justificatory discourse started to develop, especially on the side of the European Court of Justice (ECJ) and the Commission, centred on non-discrimination, equality of opportunity, transnational solidarity. ${ }^{7}$ While pertinent and highly relevant for ideal justifications - based on ultimate standpoints regarding the 'good society' - these three normative principles wield very limited political purchase in the current predicament of increased contention around free movement and access to benefits. In a number of Member States, voters express a clear preference for discrimination, despite the deliberate efforts of political education on the side of their governments. ${ }^{8}$ In fact, insisting on non-discrimination can lead to a further destabilisation of the European polity. If the goal is that of containing conflict and preserve opening, we need to look for justifications which are perhaps less ambitious, but more realistic and sensitive to consequences. Europe has a long history of admitting foreigners in domestic labour markets through 'guest-worker' regimes. As this expression

${ }^{6}$ M. Ferrera, 'Solidarity in Europe after the Crisis', (2014) 21 Constellations, 222-238; M. Ferrera, 'The European Social Union: a missing but necessary "political good”, in F. Vanderbroucke (ed.), Social Policy and the EU: Ways Forward (Cambridge University Press, forthcoming 2016).

${ }^{7}$ F. De Witte, Justice in the EU: The Emergence of Transnational Solidarity (Oxford University Press, 2015 ); A. Favell, 'The Fourth Freedom: Theories of Migration and Mobilities in "Neo-Liberal” Europe', (2014) 17 European Journal of Social Theory, 275-289.

8 S. Svallfors (ed.), Contested Welfare States: Welfare Attitudes in Europe and Beyond (Stanford University Press, 2012). 
implicitly suggests, the principle (and practice) which has traditionally guided the phenomenon of immigration is that of 'hospitality'. Elaborating on the latter may thus provide us with useful normative insights.

Hospitality has been a key value of European cultures since antiquity. Immortalised by Homer in the story of Glaucos and Diomedes (Iliad), Xenía (in Greek) or hospitium (in Latin) was a key social norm in classical times, prescribing protection and shelter, and more generally generosity and courtesy vis-à-vis those who were far from home. Its funewas that of managing and civilising external influences that might potentially be dangerous for society ex providing opportunities for beneficial exchanges and trades. ${ }^{9}$ In modern political philosophy, the principle of hospitality has a noble pedigree, rooted in Kantian thought. ${ }^{10}$ In his famous essay on perpetual peace, Kant argued that, owing to the finite size of the earth's surface, certain moral obligations arise that forbid territorial closure. The third 'definitive article of perpetual peace' defines hospitality as 'the right of a stranger not to be treated as an enemy when he arrives in the land of another... so long as he peacefully occupies his place, one may not treat him with hostility.' There are, however, two kinds of hospitality rights. The first is 'a right of temporary sojourn, a right to associate, which all men have.' For Kant this is a ius cosmopoliticum (a cosmopolitan right), which men have 'by virtue of their common possession of the surface of the earth, where, as a globe, they cannot infinitely disperse and hence must finally tolerate the presence of each other.' The second kind of hospitality is more specific and demanding: 'the right to be a permanent visitor.' A special agreement is needed in order to give an outsider the right to become a fellow inhabitant. What Kant had in mind was the ius hospitii defined by Roman law since the early Republic: the faculty enjoyed by the citizens of Rome and certain foreign cities or states to freely move into each other's territory (often by showing the tessera hospitalis) and of having the same privileges except for the suffragium (the right to vote). ${ }^{11}$

The EU citizenship regime can be partly seen as a contemporary version of the ius hospitii. The citizens of other EU nations are not, by definition, full members of the Folkhemmet. But they ought to be treated as hospites in the thick sense, entitled to equal treatment as regards civil and at least some social rights. In Roman times, the foedus hospitii (hospitality pact) was struck between civitates linked by interest-based friendship and was often preceded by a commercial treaty. A similar case can be made for the EU today. As mentioned above, the latter can be seen as a 'neighbourhood community', held together by mutually advantageous agreements of economic and political association. The introduction of rules imposing a duty of hospitality vis-à-vis citizens of neighbouring countries has prima facie both a moral and political grounding. It also serves the important function of social integration: it fosters mutual recognition and respect, fights prejudice and stereotypes, ignites processes of conversion whereby strangers are turned into fellows, friends and even members of kin, it promotes the internalisation and diffusion of liberal and cosmopolitan values.

To what extent can the principle of hospitality (in a wider context of 'sober brotherhood') serve as a 'realist' justification - in the current predicament-for framing the contested issue of transnational solidarity linked to free movement? In order to answer this

\footnotetext{
9 T. Selwyn, 'An Anthropology of Hospitality', in C. Lashley and A. Morrison (eds.), In Search of Hospitality (Butterworth-Heinemann, 2000), 18-37.

10 Ferrera, 'Solidarity in Europe after the Crisis', above, n. 6; A. Hoogenboom, 'In Search of a Rationale for the EU Citizenship Jurisprudence', (2015) 35 Oxford Journal of Legal Studies, 301-324.

11 A.N. Sherwin-White, Roman Citizenship (Oxford University Press, 1973).
} 
question, we must first take stock of the factual situation, focusing in particular on the sources and nature of ongoing conflicts.

\section{Intra-EU Mobility: The State of Play}

The right of EU citizens to freely move to and live in any Member State is one of the four fundamental freedoms enshrined in EU law. EU workers have benefited from this freedom since the late 1960s. ${ }^{12}$ In 1971, Regulation $1408^{13}$ established the following basic principles: (a) non-discrimination and equality of treatment; (b) aggregation of all periods of insurance, in whatever country; (c) benefit exportability from one Member State to another; and (d) lathe the country of work. With the Treaty of Maastricht (1992), the right to free movement was recognised for all EU citizens, whether economically active or not. In 2004, legislation and case-law seting out the conditions for and limitations on the right of residence were codified in Directive No. 38/2004. With the incorporation of the Charter of Fundamental Rights and a clear reformulation of the meaning and content of EU citizenship, the Lisbon Treaty (2009) has given to pre-existing EU laws on free movement, residence and access to social protection a constitutional status. Article 45 of the Treaty on the Functioning of the European Union enshrines the right of EU citizens to move to another Member State for work purposes, and it specifically includes the right not to be discriminated against on the ground of nationality as regards access to employment, remuneration and other conditions of work. The Charter in its turn (Article 15.2) clearly states that EU citizens have the freedom to seek employment, to work, to exercise the right of establishment and to provide services in any Member State. In 2011, Regulation $429^{14}$ has detailed the rights derived from the freedom of movement of workers, prohibiting discrimination in the following areas: access to employment, working conditions, social and tax advantages, access to training, membership of trade unions, housing and education for children. In 2014 Directive 54 has introduced measures to facilitate the exercise of rights on the side of mobile workers.

In terms of figures, about 14 million EU citizens currently reside in a different Member State (ca. 2.8 per cent of the EU population, up from 1.6 per cent prior to the Eastern enlargements). The most important receiving countries are Luxembourg, Cyprus, Ireland, Belgium, Spain, Austria, the UK, Germany, Sweden and Denmark. Intra-EU mobility flows are driven mainly by the search for jobs and better working conditions. After the onset of the financial crisis, mobility first sharply declined ( -41 per cent between 2008 and 2010) but picked up again thereafter, especially from countries in economic difficulty. EU migrants are more likely to be economically active than nationals living in the same country. If unemployed, EU mobile citizens typically ( 90 per cent) lost their jobs in their current country of residence. Economically inactive EU migrants only represent between 0.7 and 1 per cent and the vast majority of them are relatives of economically active migrants. Activity rates among EU migrants have been constantly increasing over the years. 15

12 F. Pennings, Introduction to European Social Security Law (Kluwer Law International, 2001); P.A. Van der Mei, Free Movement of Persons Within the European Community (Hart Publishing, 2003).

13 OJ L 149, 5.7.1971, 2-50.

14 OJ L 141, 27.5.2011, 1-12.

15 ICF GHK, Milieu Ltd, 'A fact finding analysis on the impact on the Member States' social security systems of the entitlements of non-active intra-EU migrants to special non-contributory cash benefits and healthcare granted on the basis of residence', (2013) Final Report KE-04-13-060-EN-N, available at http://tinyurl. com/jj17hmu (accessed 12 January 2017). 
What are the economic and financial effects of mobility? The available empirical evidence shows that intra-EU migration tends to have positive economic effects on the receiving countries. ${ }^{16}$ For the EU-15, gross domestic product (GDP) is estimated to have increased by almost 1 per cent in the long term as a result of post-enlargement mobility (2004-2009). Migrants typically help the host country's economy to function better because they help to tackle skills shortages and labour market bottlenecks. The negative effect of migration on the jobs and wages of native workers is modest in 'normal' times, but it can increase significantly during recessions, especially for the low skilled. In most Member States, mobile EU citizens are net contributors to the host country's welfare system - they pay more in tax and social security contributions than they receive in benefits. EU mobile citizens also tend to be net contributors to the costs of public services which they use in the host Member State. They are therefore unlikely to represent a burden on the welfare systems of host Member States. Due to their age and employment status, when receiving social benefits mobile EU citizens are in general more likely to be in receipt of unemployment, housing and family-related benefits than old-age, sickness or invalidity benefits. Yet they represent only a small share of those receiving such benefits, in line with their relatively low share in the total population in most Member States. Data also show that mobile EU citizens account for a very small share of recipients of special noncontributory benefits, i.e. those combining features of social security and social assistance at the same time: less than 1 per cent of all beneficiaries (who are EU citizens) in six countries (Austria, Bulgaria, Estonia, Greece, Malta and Portugal); between 1 per cent and 5 per cent in five other countries (Germany, Finland, France, the Netherlands and Sweden), and above 5 per cent in Belgium and Ireland. Recent studies conclude that there is no statistical relationship between the generosity of the welfare systems and the inflows of mobile EU citizens. ${ }^{17}$

Even if the factual answer to the 'who pays' question is that migrant workers themselves bear the burden of the benefits and services which they consume (at the aggregate level and usually also at the individual level), public opinion in the receiving countries tends to be To be sure, the principle of free movement is, in general, widely supported. According to a 2015 survey, more than three-quarters of Europeans consider that 'the right for EU citizens to work in every Member State of the EU' is a 'good thing'. ${ }^{18}$ An equally vast majority ( 74 per cent) supports 'the right for EU citizens to live in every Member State of the EU'. But if more specific questions about immigration are asked, positive views drop rather drastically. Only a slight majority of Europeans (51 per cent) show positive feelings about 'immigration from other EU Member States'. Except for the Nordic countries and a few other states, in the receiving countries negative views are higher or on a par with positive views. Negative sentiments against EU migrants tend to increase if specific groups or the costs of welfare are mentioned. According to a 2013

16 OECD, 'The Fiscal Impact of Immigration in OECD Countries', in OECD, International Migration Outlook (OECD Publishing, 2013); C. Dustmann, T. Frattini and C. Halls, 'Assessing the Fiscal Costs and Benefits of Migration to the UK', (2010) 31 Fiscal Studies, 1-41; M. Kahanec and K.F. Zimmermann (eds.), EU Labor Markets After Post-Enlargement Migration (Springer-Verlag, 2010); I. Preston, 'The Effect of Immigration on Public Finances', (2013) Centre for Research and Analysis of Migration Discussion Paper Series, CDP No. 23/13, available at http://www.cream-migration.org/publ_uploads/CDP_23_13.pdf (accessed May 2016).

17 European Commission, 'Communication on Free Movement of EU Citizens and their Families: Five Actions to Make a Difference', (2013) Brussels, 25.11.2013, COM(2013) 837 final, available at http://tinyurl.com/ guwv2qu (accessed 12 January 2017).

18 Eurobarometer, 'Public Opinion in the European Union', (2015) 84 Standard Eurobarometer, available at http://tinyurl.com/gtrfrz3 (accessed 12 January 2017). 
survey, more than 80 per cent of Britons, 73 per cent of Germans, 72 per cent of Frenchmen and 66 per cent of Italians agreed that access to benefits should be restricted for EU migrants from Eastern Europe, while two-thirds of Germans saw mobile EU citizens as a potential 'extra burden' on their country's social welfare system. ${ }^{19}$ Needless to say, intra-EU mobility remains very popular in Member States where flows originate - for example in Poland or Romania.

Reflecting and reinforcing anti-immigration trends, political parties with a restrictive agenda (typically right-wing populist parties) are becoming increasingly popular in Western Europe. In many countries, Eurosceptic narratives are dangerously associating intra-EU mobility with migration from outside the EU, which is seen much more negatively. Right-wing populism made an early appearance in the 1970s and 1980s, taking the form of anti-tax and anti-bureaucratic campaigns addressed mainly to a petite bourgeoisie of self-employed and small businesses: this is, for instance, the experience of the National Front in France or the Progress Parties in Norway and Denmark. Once established as organised political parties, however, these populist movements have gradually soft-pedalled their anti-welfare state profile, playing to other themes such as the fight against privilege and corruption, opposition to spending cuts (for native male insiders) and foreign immigration. The evolution of the Danish People's Party (DFP), the Austrian Freedom Party (FPO), the National Front (FN) in France well represents this ideological turn, which has attracted towards these formations also the support of working-class voters, made anxious by globalisation trends, economic shocks and occupational upheavals. Recent research on the determinants of negative attitudes towards intraEU mobility has shown that the latter are typically associated with the socio-economic vulnerability of respondents, thus confirming the insight of 'threat theory': negative perceptions increase in contexts characterised by competition over scarce resources (jobs, services) as well as the size and the cultural distance of the outgroup. ${ }^{20}$ In the Netherlands, France, Italy and especially the UK, populist parties call for an exclusionary reorientation of existing welfare state schemes, creating a sharper divide between nationals and members of other EU countries, nationals and extra-EU migrants, let alone illegal immigrants. More generally, such parties have adopted marked souverainiste profiles and have launched an overall attack against integration and the EU as such. Rising migration flows and inter-cultural relations have brought fuel also to the various ethno-regionalist parties, pushing them to enhance their anti-immigration profiles and making the defence against immigrants a top priority of their policy agenda. The growing presence and visibility of 'otherness' allows these parties to magnify and mythologise local/ethnic cultural forms, often through historical manipulation. The local Gemeinschaft is thus presented as the natural place for identity-based forms of exclusionary sharing, highly reluctant to open themselves to strangers, and even neighbours. The increasing appeal and social entrenchment of such mindsets erodes the cultural predispositions for the acceptance and practice of the ius hospitii, let alone the much more demanding principle of non-discrimination. Is there a way to counter this dangerous drift and restore the symbolic purchase of the tradition of 'hospitality'?

19 The Harris Poll Global Omnibus, J110757w41 October 2013, Harris Interactive, A729_Ft Immigration, Field Period: 8th October-14th October 2013; available at: http://im.ft-static.com/content/images/ 8caa41b8-383e-11e3-8668-00144feab7de.pdf (accessed 12 January 2017).

20 Y. Solamonska, 'Free Movers or Immigrants? Attitudes to Migration from EWU Countries', poster presented at the Eurobarometer Symposiuum, Cologne, 10 June 2015; available at: http://www.gesis.org/fileadmin/upload/events/EB-Symposium/Poster/Salamonska_Poster.pdf (accessed May 2016). 


\section{The Principle of Hospitality and its Practical Effects}

As in all forms of solidarity, a prime driver of hospitable predispositions are reciprocity expectations. In the case of migrants and their admission into national labour markets or welfare systems, however, the specific form and content of expectations are more difficult to pin down than in the case of cross-national solidarity through material assistance. In the latter case, the maxim is 'I transfer to you — from my to your place - something now because you are in need and you will give back something of the same sort later'; in the former the exchange matrix is much more vague. What is 'given' are essentially positive predispositions on the side of the hosting party: 'I admit you into my place and pledge to treat you as a fellow citizen.' True, the host may expect to become a guest of her guest at a later time and to count on equally hospitable dispositions. But, more often, the reciprocity expectation of the host is addressed to returns in other ambits, or it may be a mere expectation of good conduct. In other words, hospitality does entail mutual connection and indebtedness, but the latter's nature and size remain rather vague. A second element which weakens reciprocity in the context of migration-based hospitality is this: apart from extraordinary cases (refugees, asylum seekers), migrants - especially intra-EU migrants are not necessarily in conditions of extreme need or emergency. They are strangers seeking a better fortune who knock at the doors of 'our' Folkhemmet without invitation, but with a legal right to enter. Some inhabitants of the hosting space may be afraid to open the doors; they do not know what to expect. Studies in the etymology of the word 'hospitality' (including its Germanic equivalents) have found that its historical connotations are not limited to openness, protection, acceptance, but also to hostility, violence, hostage: in a word, enmity. ${ }^{21}$ The stranger seeking hospitality may be moved by predatory aims. If forced to open the doors, the host may be tempted to respond with the same coin, e.g. by overtly or covertly exploiting the guest.

To a large extent, such developments are already unfolding throughout Europe. The rapid increase in a relatively short period of time of foreign immigrants - even if from other 'neighbouring' Member States - in a given national community tends to disturb the existing distribution of material resources and life chances among natives and often challenges (or is perceived as a challenge to) the prevailing cultural norms and symbolic codes. Contrary to resource transfers between Member States - i.e. cross-national solidarity - the sharing of national resources with non-nationals cuts deep into the fabric of society, affecting less the macro than the micro level. Moreover, cross-national transfers are typically linked to emergencies or crises. And even when they originate long temporal commitments, transactions take place far from the attention and personal experience of the individual insiders. By contrast, the entry of outsiders is a visible, almost tangible development, which inevitably elicits the attention and often the voice of insiders. In the field of social protection, immigration allows outsiders to penetrate (at least partially) the national sharing space. As mentioned above, the establishment of EU social rights has not resulted from resource pooling in a common central 'pot', as in national welfare states. The obstacles to expand the EU budget and powers were (and still are) and social security coordination, instead of supranationalisation, was probably the only feasible solution. But it was also fraught with serious institutional and political implications.

EU citizenship is a second order status which supervenes on national citizenship. Its


authority which confers such right-i.e. the EU-'produces' a new guaranteed power

21 E. Benveniste, Indo-European Languages and Society (Faber and Faber, 1973). 
(a legal right) for mobile citizens by allowing them to participate in the social sharing arrangements of the Member State in which they choose to work and reside. As is the case in all forms of power, the production of free movement rights involves corresponding duties, i.e. the duty to accept free movers and respect their rights. Such duties fall essentially on the shoulders on non-mobile natives. Contrary to what happens at the national level, the social component of EU citizenship rests on regulation, not on allocation (i.e. the creation of entitlements by the conferring institution directly funded through tax extractions on the side of that institution). While in line with the treaties and largely reasonable in economic/functional terms, this approach has generated significant political asymmetries: in fact, it has empowered a relatively small constituency of mobile citizens, at the (perceived) expense of large majorities of nonmobile natives. In the medium and large EU countries, more than half of the natives have always lived in the region where they were born and raised and hardly expect to exercise the rights of free movement themselves. On average, large majorities of nationals have never visited another EU country, watched TV or read a book in another language, used the internet to purchase goods from abroad. ${ }^{22}$ It is not surprising that many of these people perceive the rights of immigrants as a loss in the value of their own rights and opportunities within their own communities. There is some evidence that these perceptions are not entirely unwarranted (especially as regards access to public services or housing prices). ${ }^{23}$ As mentioned above, such perceptions are stronger among the less educated and within poorer areas, where vulnerability is higher and immigration is seen as a threat in the competition for scarce resources.

The social politics of intra-EU migration offers numerous examples of both 'predation' and 'exploitation.' Welfare tourism is limited and much less widespread than perceived, but it does take place. In some moments and countries, the occurrence of 'social raids' has been documented, i.e. 'surprise attacks on national social security carried out by a small or large group of people from abroad'. ${ }^{24}$ Its protagonists are able-bodied workers and their families who strategically obtain a work permit (not necessarily a genuine one) or take advantage of regulatory loopholes in order to capture social benefits with minimum effort, possibly exporting them to their home country. There is also evidence of fraudulent accumulation of benefits, e.g. unemployment subsidies from both the host and the home countries. ${ }^{25}$ At the other end of the spectrum, we find several examples of exploitation or at least unfair treatment: discrimination in terms of recruitment and working conditions (remuneration, career prospects, social advantages, unrecognised professional qualifications and so on. ${ }^{26}$ There is also evidence of criminal forms of labour exploitation affecting workers moving within (or into) the EU. Exploitation is extensive in a number of industries,particularly agriculture, construction, hotel and catering, domestic work and manufacturing and at little risk of prosecution or of having to compensate victims. The possible predatory and

22 Eurobarometer, above, n. 18.

23 S. Vargas, 'EU Migration to the UK: Trends and Impacts', (2014) 49 Intereconomics, 123-128.

24 J. Kvist, 'Does EU Enlargement Start a Race to the Bottom? Strategic Interaction among EU Member States in Social Policy', (2004) 14 Journal of European Social Policy, 301-318, at 306.

25 P.J. Dittrich and N. Spath, 'De Jure Freedom of Movement and De Facto Mobility in the EU Internal Market', (2016) Jacques Delors Institut, Policy Paper n. 161, available at http://www.delorsinstitut.de/2015/wpcontent/uploads/2016/04/LabourMobility-DittrichSpath-JDIB-April16.pdf (accessed May 2016).

${ }^{26}$ Favell, above, n. 7; L. Pradella, 'Labour, Exploitation and Migration in Western Europe: An International Political Economy Perspective', in G. Craig, L. Waite, H. Lewis and K. Skrivankova (eds.), Vulnerability, Exploitation and Migrants: Insecure Work in a Globalised Economy (Palgrave, 2015), 44-56. 
exploitative degenerations of hospitality expose it to the risks of antagonisms and social polarisations.

Two developments have amplified and exacerbated the dark sides of hospitality politics during the last years. First and obviously, the financial crisis. On the one hand, the latter has prompted a surge of migration from East and South towards the North. During the crisis years 2008-2012 EU migration to the UK amounted to more than 300,000 net arrivals. On the other hand, it has impoverished a number of low income groups in the receiving countries, inflaming their anxieties and fears. Second, there has been a massive increase in migration flows from outside the EU, especially in the wake of the Libyan and Syrian crises. This development has cast an additional halo of negativity onto intraEU migration as well.

Hospitality principles, norms and dispositions are necessary conditions for upholding intra-EU mobility cum social protection rights. Without such conditions, free movement becomes politically unviable and the EU is doomed to drift backwards into a 'fortress of fortresses' - a drift accompanied by a politics of acute contention and escalating polarisation within and across countries. Are there ways of avoiding this scenario?

\section{How to Make Intra-EU Migration Politically Sustainable}

Political and social theory has not fully the manifold aspects of the principle and practice of hospitality. Two precious insights can, however, be derived from this literature and both have to do with the setting of constraints. As far as the guest is concerned, constraints should be placed at various points of the path from 'outsiderhood' to full 'insiderhood.' As far as the host is concerned, constraints should be introduced to safeguard fair treatment. Historically/anthropologically, these two types of constraints can be traced back to the Greek notion and practice of Xenia, which rested on two basic rules: (1) the respect from host to guest, extending to the duty of providing him/her with material comfort; (2) the respect from guest to host, implying a duty not to be a burden.

From a normative perspective, even if some authors defend the position that hospitality ought to be unconditional, ${ }^{27}$ the prevailing view is that conditionality is acceptable and reasonable - as already argued by Kant. The conditionality principle allows the host to set clauses for accepting guests: for example, in terms of explicit quid pro quos, in terms of the functional scope of hospitality, in terms of time and timing. The constraints addressed to the host can be justified based on general arguments from fairness or on more specific arguments from non-domination. According to the latter, the host must abstain from using her positional power for arbitrary and exploitative interferences in the choices of the guest, whose very status generates social and political vulnerability. Inthis view, following Honohan, a non-dominating policy on migration should rest on 'establishing the legal status of migrants, and recognising their equality in respects other than admission; applying the rule of law to migration controls by limiting arbitrary powers and constraining discretionary procedures; making accountable the institutions determining migration law and policies by the introduction of a higher regulatory authority; and, finally, making migration law and policy contestable in some way by those who are subjected to them. ${ }^{28}$ From an empirical perspective, the aim of 'non-dominating conditionality' is that of pre-empting both predation on the side of guests (and in

27 J. Derrida and A. Dufourmantelle, Of Hospitality (Stanford University Press, 2000).

28 I. Honohan, 'Domination and Migration: An Alternative Approach to the Legitimacy of Migration Controls' (2014) 17 Critical Review of International Social and Political Philosophy, 31-48, at 42. 
particular the above-mentioned 'social raids') and exploitation on the side of hosts (especially criminal abuses against low skilled migrants).

To some extent at least, something akin to non-dominating conditionality is already at work in the realm of free movement and EU social citizenship in particular. True, the existing treaties are very clear: freedom of movement of workers/persons is a core principle of the European construction. But at the 'constitutional' level the rules are very general. De facto, the free movement of workers/persons and especially their access to social benefits are regulated by secondary legislation and the jurisprudence of the Court of Justice of the European Union - in ways that often create incoherence and unjustified differentiations. ${ }^{29}$ It is at this level that solutions must be sought in order to contain the increasingly contentious and polarised politics of hospitality. The balance now existing between opening and closure should be recalibrated to take account of the sensitivity of certain countries' public opinion and of the demands of their governments, especially the British.

More concretely, what might be done is a more stringent definition of the rights of those who do not work: for example, the relatives who remain in the countries of origin (e.g., with regard to family allowances), residents who are not economically active, and to some extent also those who move in search of work. ${ }^{30}$ Partly, this can be done by applying more severely the restrictive clauses that already exist: Germany, Austria and the United Kingdom already have moved along this path. It is clear that the freedom of movement of workers and their entitlement to social security benefits should remain a 'red line' not to be crossed (as demanded by the countries of Central and Eastern Europe). On other types of intra-EU migrants, however, it is reasonable to recognise that the pan-European solidarity now politically viable is more limited than that provided for by the regulatory status quo. Provided that it does not trespass the 'red line' (the minimum level of solidarity which is necessary to speak of an EU common social space supporting free movement), it would not be a drama to give back to the Member States a modicum of autonomy in filtering the access to social benefits on the side of nonnational inactive or non-resident persons. A redirection in this sense is already detectable in recent ECJ rulings and doctrine. ${ }^{31}$ In parallel with the recognition of greater autonomy to national governments, one might also consider a more explicit involvement of the EU in bearing the costs related to the free movement-of workers. Some proposals have already been made, including the creation of a dedicated social insurance scheme of mobile workers or (more realistically) the establishment of a fund for supporting some of the costs borne by local communities where burdens in terms of access to welfare services are concentrated. ${ }^{32}$

In the current, highly contentious predicament, a politically sustainable migration policy in the EU should rest on three distinct rationales. First, a functional rationale: encouraging/allowing that intra-EU mobility which is driven by economic supply and demand, discouraging instead those flows that are empirically proven to be harmful to migrants themselves and/or the host society. Second, a normative rationale: admitting EU migrants follows from the mutual advantages of hospitality (a softer variant of non-

${ }^{29}$ C. Bruzielius, C. Reinprecht and M. Seeleib-Kaiser (eds.), 'EU Migrant Citizens, Welfare States and Social Rights', Paper prepared for presentation at the 23rd International Conference of Europeanists, Philadelphia, PA, 14-16 April 2016.

${ }^{30}$ Dittrich and Spath, above, n. 25.

${ }^{31}$ De Witte, above, n. 7.

${ }^{32}$ L. Andor, 'Labour Mobility in the EU', speech delivered at the University of Ghent, 25 September 2014, available at http://europa.eu/rapid/press-release_SPEECH-14-622_en.htm (accessed 12 January 2017). 
discrimination); the corresponding rights and duties must, however, be carefully designed to avoid both predation and exploitation. Last, but not least, a political rationale: choosing policies capable of balancing opening and closure in order not to jeopardise at least a minimal threshold of solidarity for the survival of the EU polity as such.

\section{Conclusion}

In the wake of the Eastern enlargement, the Great Recession and, more recently, the refugee crisis, the EU has been witnessing a growing tension around the issue of boundaries and is facing an increasing difficulty in reconciling the logic of closure, which underpins national dispositions and practices of social sharing, and the logic of opening, which has typically inspired the integration project. Adopting a realist perspective on the link between facts and principles, this paper has argued that the most promising normative framings for the contentious politics of pan-European solidarity should rest on the norms of 'sober brotherhood' (for cross-national solidarity) and 'non-dominating hospitality' (for transnational solidarity). The latter seems particularly suitable for addressing the growing opposition to intra-EU mobility and the access to social benefits on the side of EU migrants. While non-discrimination, as enshrined in the treaties, should certainly remain the 'first principle' to defend free movement from a legal and moral point of view, the political appeal to a less demanding principle such as hospitality promises to be more in line (and thus more effective in softening conflicts) with ongoing factual developments.

th will certainly not be easy for the EU to find a balance between closure and opening: a balance capable of sustaining brotherhood and hospitality under changed boundary conditions. The nation-state still is, and probably will remain for a long time, the ultimate guarantor of entitlements and the prime legitimate space for the exercise of social citizenship and for the delicate balancing of rights and obligations. The challenge is not that of overcoming the nation-state in its social integration functions, but that of nesting national sharing traditions within wider membership spaces, thus containing destructuring pressures and possibly activating cross-national bonding dynamics. There is no doubt that 'opening' has already brought and can continue to bring enormous economic benefits. But, even if actually perceived (a big if), the latter are an insufficient condition for the political viability of free movement. The balance between opening and closure must be produced by politics: it can only result from a laborious process of consensus building within and among the Member States, blending interests, ideas and values.

First submission:

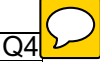

Final draft accepted:

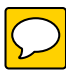




\section{Author Query Form}

\section{Journal: European Law Journal}

\section{Article: eulj_12209}

Dear Author,

During the copyediting of your paper, the following queries arose. Please respond to these by annotating your proofs with the necessary changes/additions.

- If you intend to annotate your proof electronically, please refer to the E-annotation guidelines.

- If you intend to annotate your proof by means of hard-copy mark-up, please use the standard proofing marks. If manually writing corrections on your proof and returning it by fax, do not write too close to the edge of the paper. Please remember that illegible mark-ups may delay publication.

Whether you opt for hard-copy or electronic annotation of your proofs, we recommend that you provide additional clarification of answers to queries by entering your answers on the query sheet, in addition to the text mark-up.

\begin{tabular}{|c|l|c|}
\hline Query No. & \multicolumn{1}{|c|}{ Query } & Remark \\
\hline Q1 & $\begin{array}{l}\text { AUTHOR: Please provide an abstract section of } \\
\text { between 100 and 150 words. }\end{array}$ \\
\hline Q2 & $\begin{array}{l}\text { AUTHOR: Second reference in note 6 is still unlisted } \\
\text { on the CUP website, so perhaps change date to 2017. } \\
\text { Also has book title been changed to "A Social Union } \\
\text { after the Crisis"? }\end{array}$ \\
\hline Q3 & $\begin{array}{l}\text { AUTHOR: Please confirm that given name (red) and } \\
\text { surname/family name (green) have been identified } \\
\text { correctly. }\end{array}$ \\
\hline Q4 & WILEY: Please provide history dates. \\
\hline
\end{tabular}


Required software to e-Annotate PDFs: Adobe Acrobat Professional or Adobe Reader (version 7.0 or above). (Note that this document uses screenshots from Adobe Reader $\mathrm{X}$ )

The latest version of Acrobat Reader can be downloaded for free at: http://get.adobe.com/uk/reader/

Once you have Acrobat Reader open on your computer, click on the Comment tab at the right of the toolbar:

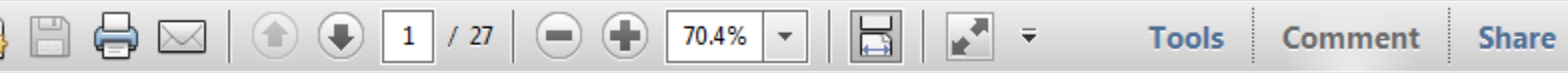

This will open up a panel down the right side of the document. The majority of tools you will use for annotating your proof will be in the Annotations section, pictured opposite. We've picked out some of these tools below:

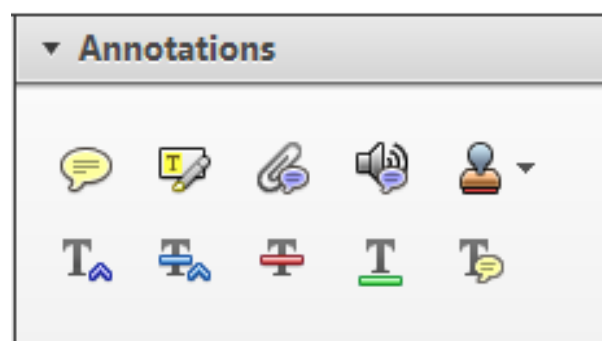

1. Replace (Ins) Tool - for replacing text.

Strikes a line through text and opens up a text box where replacement text can be entered.

How to use it

- Highlight a word or sentence.

- Click on the Replace (Ins) icon in the Annotations section.

- Type the replacement text into the blue box that appears.

Idard tramework for the analysis of $\mathrm{m}$ icy-Nevertheless, it also led to exog،

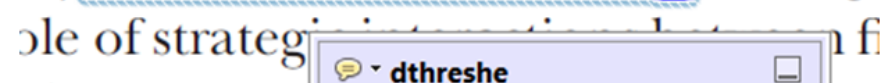
aber of comp 08/06/2011 15:58:17 is that the s1 nain compo: be level, are exc nc

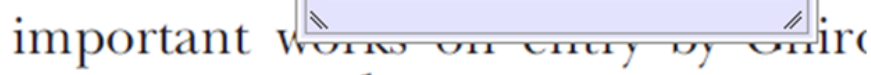
M heneferth) ${ }^{1}$ we anen the "hlarl $\mathrm{l}$

3. Add note to text Tool - for highlighting a section to be changed to bold or italic.

T Highlights text in yellow and opens up a text box where comments can be entered.

\section{How to use it}

- Highlight the relevant section of text.

- Click on the Add note to text icon in the Annotations section.

- Type instruction on what should be changed regarding the text into the yellow box that appears.

namic responses of mark ups ent with the VAR evidence

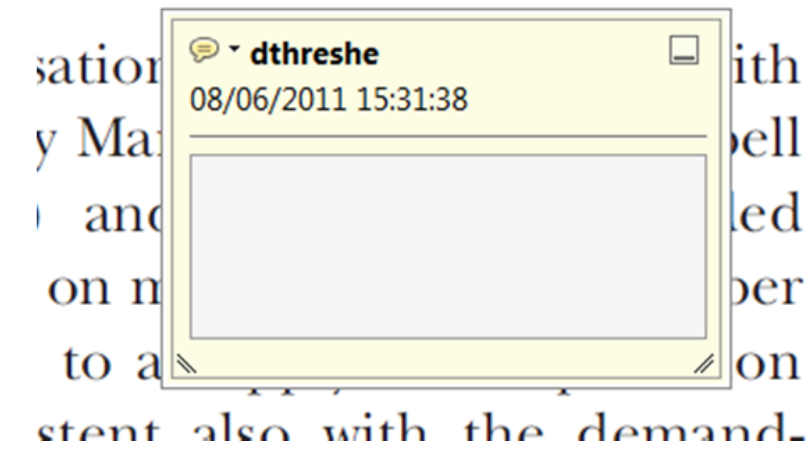

2. Strikethrough (Del) Tool - for deleting text.

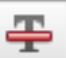

Strikes a red line through text that is to be deleted.

How to use it

- Highlight a word or sentence.

- Click on the Strikethrough (Del) icon in the Annotations section.

there is no room tor extra prohts al c ups are zero and the number of ret) values are not determined by Blanchard and Kiyotaki (1987), sfect competition in general equilil ts of aggregate demand and supply lassical framework assuming monol eph on evorenous number of firme

4. Add sticky note Tool - for making notes at specific points in the text.

Marks a point in the proof where a comment needs to be highlighted.

How to use it

- Click on the Add sticky note icon in the Annotations section.

- Click at the point in the proof where the comment should be inserted.

- Type the comment into the yellow box that appears.

iaisu airu suppiy sirucks. hivsl ui

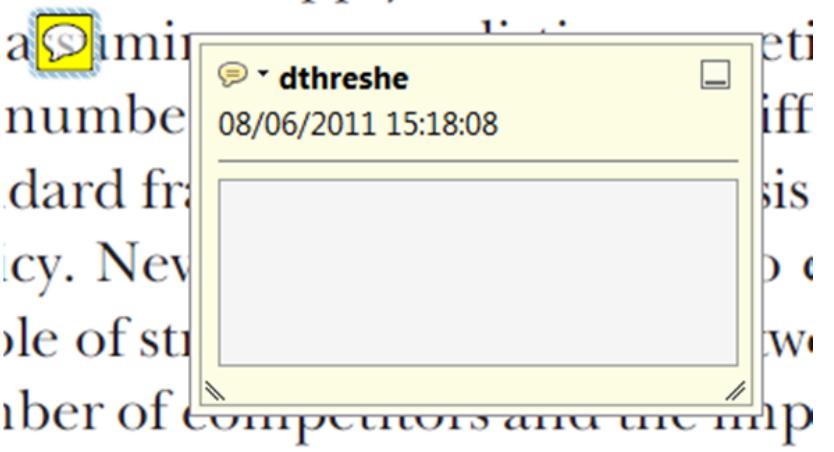

is that the structure of the secto. 
5. Attach File Tool - for inserting large amounts of text or replacement figures.

Inserts an icon linking to the attached file in the appropriate pace in the text.

How to use it

- Click on the Attach File icon in the Annotations section.

- Click on the proof to where you'd like the attached file to be linked.

- Select the file to be attached from your computer or network.

- Select the colour and type of icon that will appear in the proof. Click OK.

E N D

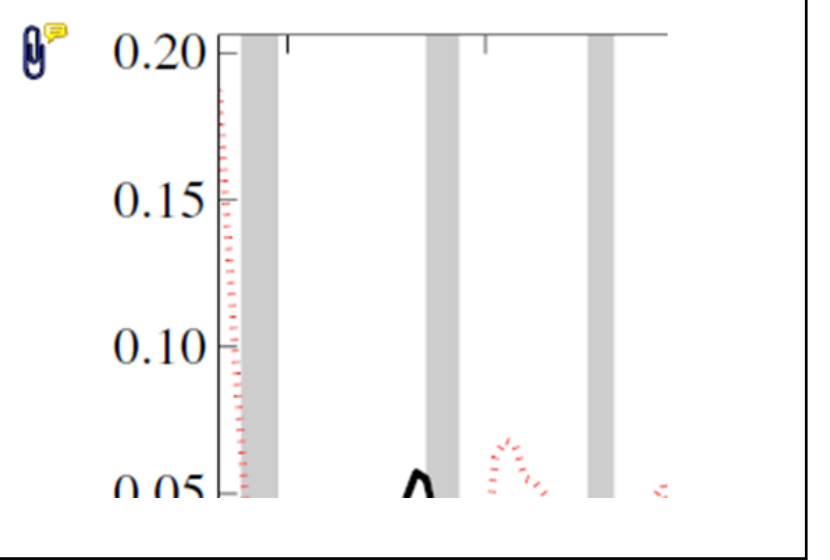

6. Add stamp Tool - for approving a proof if no corrections are required.

- Inserts a selected stamp onto an appropriate place in the proof.

\section{How to use it}

- Click on the Add stamp icon in the Annotations section.

- $\quad$ Select the stamp you want to use. (The Approved stamp is usually available directly in the menu that appears).

- Click on the proof where you'd like the stamp to appear. (Where a proof is to be approved as it is, this would normally be on the first page).

or the business cycie, starting with the on perfect competition, constant ret

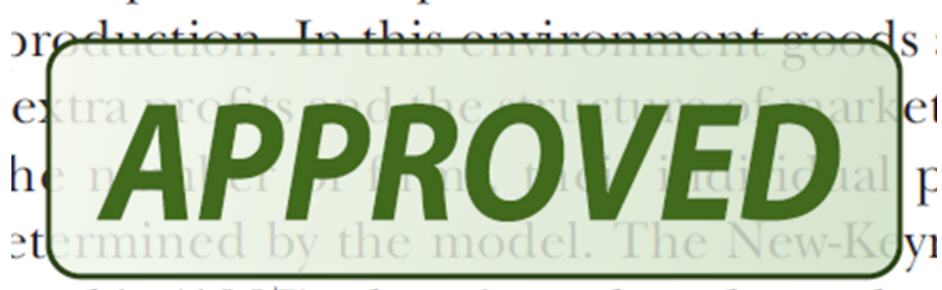
otaki (1987), has introduced produc general equilibrium models with nomin:

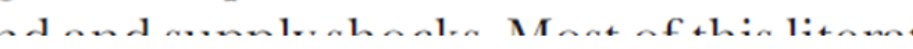

- Drawing Markups

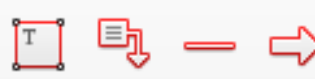

$0 \bigcirc \sqrt{6} \otimes$

\section{How to use it}

- Click on one of the shapes in the Drawing Markups section.

- Click on the proof at the relevant point and draw the selected shape with the cursor.

- To add a comment to the drawn shape, move the cursor over the shape until an arrowhead appears.

- Double click on the shape and type any text in the red box that appears.
7. Drawing Markups Tools - for drawing shapes, lines and freeform annotations on proofs and commenting on these marks.

Allows shapes, lines and freeform annotations to be drawn on proofs and for comment to be made on these marks.

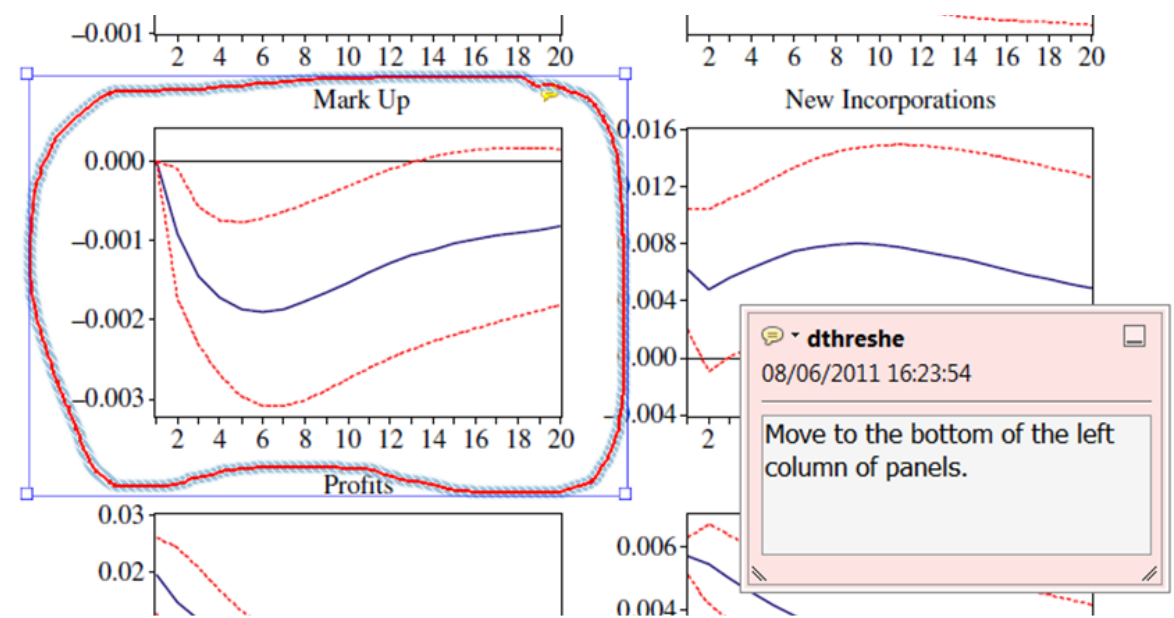

For further information on how to annotate proofs, click on the Help menu to reveal a list of further options:



